\title{
1947 California Corporations Code and Other Corporations Legislation
}

\author{
Harriett R. Buhler*
}

$A_{\text {Corporations Code }{ }^{1} \text { the nineteenth of the subject-codes prepared }} 1947$ regular session the California legislature enacted the by the California Code Commission. ${ }^{2}$ The statute empowering the Code Commission to revise all the laws of the state expressly includes "the correction of errors in form or substance" within the work of revision. ${ }^{3}$ The Commission, however, has adhered to the policy of not proposing substantive changes as a part of codification, but rather of compiling, consolidating, rearranging, and restating the law without change in legal effect. The laws and code sections allocated by the Commission to a particular proposed code are compiled, carefully examined to determine whether they are in full legal effect or have been superseded or impliedly repealed by subsequent legislation; and those which are clearly obsolete are scheduled for explicit repeal.

The remainder, the "live law" in the field, is arranged in logical sequence. The first portion of each code presented to the legislature by the Code Commission consists of general provisions comprising the short title of the code; a declaration that the provisions of the code, insofar as they are substantially the same as existing statutory provisions relating to the same subject matter, are to be construed as restatements and continuations, and not as new enactments; saving clauses in respect to continuation in office of persons holding office under acts repealed by the code, and as to rights accrued and actions and proceedings commenced prior to the effective date of the code; rules of construction and definitions common to all of the codes; and a separability clause.

If the code is to be administered by a particular state agency, provisions for the establishment or continuation and for the organization of that agency often, but not invariably, are placed next in order,

*A.B. 1924, M.A. 1926, J.D. 1930, University of California; Deputy Legislative Counsel, State of California, and draftsman of the Corporations Code.

1 Cal. Stats. 1947 , ch. 1038.

2 See Cal. Stats. 1929, p. 1427 ; CaL. Gov't Code $\$ \S 10300-10351$.

3. Ibid. § 10331 (d). 
preceding a more detailed statement of the powers of the agency, and the laws which it administers. Other statutes are placed in the code in whatever order appears to be both logical and useful.

In the actual drafting hiberal use is made of definitions to secure accuracy and avoid repetition of long phrases and clauses which make reading difficult. Every effort is made to state the substance of the law as simply and directly as possible, in accordance with the canons of good grammar and rhetoric. Thus, "shall" having been defined as mandatory, the Code Commission draftsmen substitute "the director shall" for "the director is hereby authorized and directed to ....." Similarly, when a power is to be granted or a duty imposed, the active voice is preferred to the passive, to avoid uncertainty as to the person in whom the power is vested or upon whom the duty is imposed.

The anomalous "and/or", which is consistently frowned upon by the courts for uncertainty, is replaced by the appropriate conjunctive or disjunctive; or, in a proper case it is replaced by " ... or ..., or both", or by similar phrases accurately expressing the legislative intention.

Where feasible, long sections are divided into several short sections in order to facilitate reference. Moreover, when amendments to the law are proposed, the entire text of the section amended must be set forth in the legislative act in conpliance with the republication requirement of the constitution; ${ }^{4}$ the use of short sections not only minimizes the chance of unintentional change in the law through printing errors, but also effectuates a considerable saving to the state in cost of typesetting, proof-reading, etc. This is illustrated by chapter 247 of the statutes of 1941, in which corresponding amendments were made to the Retail Sales Tax Act of 1933 and the Use Tax Act of 1935 , and to the codification of those acts in the Revenue and Taxation Code enacted at that session. The amendments directed to the code required approximately seven pages, while those directed to the acts codified required approximately twenty-six pages.

The Corporations Code assembles, consolidates and revises the laws relating to general corporations, nonprofit corporations, corporations for various special purposes (such as cooperative corporations), umincorporated associations, and subversive orgamizations. In the course of preparation of the code, nimeographed copies were mailed to interested persons, including members of the 1931 State Bar Committee on Revision of the Corporation Laws, attorneys engaged in the

4 Car. Const. (1945) art. IV, § 24. 
active practice of corporation law, law teachers, authors of books and law review articles on California corporation laws, and state officials administering such laws. In response to suggestions from such persons, various minor changes were nuade in the text of the proposed code so as to set forth the existing law more accurately and clearly.

The Corporations Code codification program enacted consists of chapters 1038, 1090,1091, and 1232 of the statutes of 1947. Chapter 1038, together with chapter 1232 (making corrective amendments), makes no substantive change in the law, but rearranges and restates in simplified language the substance of existing laws, and repeals obsolete and superseded statutes, as well as the laws codified.

Chapter 1232 corrects drafting errors and omissions in chapter 1038 , to prevent any such error from resulting in a substantive change in the law. (This bill was introduced and enacted to avoid the necessity of amending chapter 1038 in course of passage.) Specifically, it makes the following corrections:

1) Corporations Code section 810 codifies subdivision 1 of Civil Code section 310 , which provided that an individual director should not be removed if there were cast against his removal votes of a number of shares which, if cumulatively voted at an election of the full board, would be sufficient to elect one or inore directors. Section 810 expresses that principle more definitely by setting forth a formula. This formula is not accurate where a class or series of shares is entitled to elect one or more directors unless it is applied to the vote of that class or series, rather than to the vote of the outstanding shares as a whole. Chapter 1232 adds to the section a provision that in such case the formula applies to the vote of that class or series.

2) Section 829 was amended to restore the phrase "firm of accountants" heretofore in the 8th paragraph of section 363 of the Civil Code, which was omitted in codification.

3) Section 1311, added to the Corporations Code by chapter 1232, codifies Civil Code section 322a, giving any shareholder who pays a debt of the corporation, because of his proportionate shareholder's liability under the statute in force prior to 1931, a right of subrogation to the claim of the creditor against the corporation. This section was omitted from chapter 1038 as obsolete, because under ordinary circumstances the three-year period of limitations on the shareholder's liability would have expired August 14, 1934. However, the Code Commission learned that the Statute of Limitations had been waived in numerous cases, and may have been tolled in others.

4) Section 2214 was amended to add a reference to allotment of rights inadvertently omitted.

5) Section 4109 was amended to delete a provision concerning the contents of the notice of approval of an agreement of merger or con- 
solidation which was not contained in the Civil Code, and which, therefore, aunounted to a substantive change deemed inappropriate in the codification, however desirable it might be for the protection of shareholders' interests. As amended, the section makes explicit the requirement (heretofore inplicit in subdivision 2 of Civil Code section 369) that notice of approval be given to shareholders, but the statute does not now provide the contents of the notice.

Chapter 1090 amends section 411 of the Code of Civil Procedure, relating to service of summons. Cross-references to Civil Code sections are changed so as to refer to the corresponding sections in the Corporations Code.

Chapter 1091 repeals section 653.4 of the Civil Code, relating to the fees of the Secretary of State for filing instruments of cooperative corporations, and adds its substance, as section 12204.5 , to the Government Code article on the fees of the Secretary of State; this article includes his fees for filing instruments of other corporations.

In addition to the bills comprising the Corporations Code codification program, the Code Commission also prepared and recommended three measures to clarify ambiguities and to supply deficiencies in the law. These bills, presented to the legislature as making substantive changes in the law, were enacted as chapters 1119,1230 and 1231.

Corporations Code section 1713 codifies the 4th paragraph of Civil Code section $342 \mathrm{a}$, providing that when a corporation acquires its own shares, if its articles prohibit their reissue, the authorized number of shares is reduced by the number of shares acquired. No public record has heretofore been required to be made of such a reduction, so that the articles of incorporation on file in the offices of the Secretary of State and the county clerk continue to state an authorized number of shares greater than the number actually authorized, unless the corporation voluntarily amends its articles to make the statement in the articles correspond with the facts.

Chapter 1119 requires that when such a reduction in the authorized number of shares occurs, the articles of incorporation must be amended to reflect the reduction, and a certificate of amendment filed. This is to be done in accordance "with the provisions governing other amendments to the articles, except that the votes or consents of shareholders are not required for the adoption of such an amendment. (Adoption by votes or consents is, however, not prohibited, so that the amendment may be adopted either in the usual manner, or without action by the shareholders, the reduction having in fact already occurred by operation of law.) If the amendment is made without votes 
or consents, the certificate is to set forth facts showing that it is made pursuant to section 1713 .

Chapter 1119 also clarifies the provision for reduction in the number of authorized shares. It specifies that the number of authorized shares of the class and series, if any, to which the acquired shares belonged is reduced by the number of these shares.

Chapter 1230 repeals provisions of the General Corporation Law authorizing provision in the bylaws of nonstock corporations for qualifications of members, acquisition, transfer, and termination of membership, classes of membership, and property, voting, and other rights, interests, and privileges of members; ${ }^{5}$ this chapter also repeals provisions relating to levy and collection of dues and assessments by nonstock corporations. ${ }^{6}$ All of these provisions are duplicated, as to nonprofit corporations, in the General Nonprofit Corporation Law, except for one sentence directly authorizing the levy of dues and assessments, which is placed in the General Nonprofit Corporation $\mathrm{Law}^{8}$ and made applicable only to nonprofit corporations.

Whether or not this alteration makes any substantive change in the law depends upon whether nonstock corporations for profit (as distinguished from nonprofit corporations) were recognized and permitted by virtue of these provisions referring to "nonstock" (rather than "nonprofit") corporations. Since 1943 the law has not been clear on this point.

Nonstock corporations for profit were contemplated in the General Corporation Law prior to 1943, by subdivision 8 of Civil Code section 290 (which required the articles of incorporation to state. that a corporation was not to be authorized to issue shares of stock if such were the fact, and authorized provision in the articles or bylaws on the subjects of the sections repealed by chapter 1230), and by subdivision 13 of Civil Code section 303 (which then authorized provision in the bylaws for the time and manner in which profits might be divided or distributed among members of nonstock corporations for profit), as well as by the provisions repealed by chapter 1230. However, these provisions were deleted in $1943 .^{\circ}$

It is very probable that the effect of the 1943 amendments was the elimination of authorization for or recognition of nonstock cor-

5 CoRporattons CODE $\S 501.5$.

6 Ibid. $\$ 2715$.

7 Ibid. $\S 99301,9402,9403$.

8 Ibid. $\$ 9611$.

${ }^{9}$ Cal. Stats. 1943, p. 2730. 
porations for profit, leaving the provisions now repealed applicable only to nonprofit corporations. In that case, chapter 1230 merely eliminates duplication of provisions. If, lowever, such corporations continued to be authorized and recognized after 1943, such authorization and recognition have now been withdrawn by chapter $1230 .{ }^{10}$

Chapter 1231 amends various sections of the Corporations Code relating to provision for debts and liabilities by corporations in process of winding up and dissolution.

The assets of a corporation in process of winding up and dissolution may be distributed to the shareliolders only after the directors have determined that all the known debts and liabilities of the corporation have been paid or adequately provided for (Corporations Code section 5000 codifying the first two sentences of the 1st paragrapl of Civil Code section 401a). Section 5001 of the Corporations Code (Civil Code section 401a, 2d paragraph) declared that the payment of a debt or liability has been adequately provided for if payment thereof has been assumed or guaranteed in good faith by one or more financially responsible corporations or other persons. However, section 5010 (4th paragraph and part of 5th paragraph, Civil Code section 403d) provided that if there is any unclaimed deposit or dividend or debt owed by a dissolving corporation to any person whose whereabouts is unknown to the persons conducting the winding up, they "shall" deposit the amount due with the State Treasurer or with some bank or trust company in the state to be paid over to the person entitled to it.

While it was generally agreed that assumption or guarantee pursuant to section 5001 was not an exclusive means of providing for debts and liabilities, it was not clear whether section 5010, as a special and mandatory means of providing for debts to creditors whose whereabouts are not known, was an exclusive means of providing for these debts, or whether they too might be provided for by assumption or guarantee. The former appeared the more probable interpretation, but there seemed no substantial reason to require different provision for payment of debts according to whether or not the whereabouts of the creditors are known, and in some instances it would be highly advantageous to the corporation, without any disadvantage to the cred-

10 A nonstock corporation for profit would be an anomaly, as the only provision for establishing a stated capital (and so for limitations on dividends and purchase of own shares) is in connection with the issue of shares. There would accordingly be no statutory safeguards for creditors. Ballantine, Corporations (Rev. ed. 1946) 29, $478-480,571-573,609,610$. 
itor, if debts to those whose whereabouts are not known could be provided for by assumption rather than deposit. For example, a corporation which had defense or war contracts with the federal government may owe considerable sums arising out of retroactive wage imcreases to workmen who cannot now be located, and at the same time have an offsetting claim against the federal government for the increases. The federal government could assume the liability to the workmen, and the corporation could distribute its assets and dissolve, if our law permitted that provision for such debts. Otherwise, the only way the corporation could distribute its assets and dissolve was to deposit the amount due to the creditors, without the ability to collect from the federal government, and after three years to distribute the amount deposited, if it were still unclaimed.

Chapter 1231 amends section 5001 to provide that payment. of a debt or liability is adequately provided for, whether the whereabouts of the creditor is known or unknown, if it is either assumed or guaranteed as formerly provided in the section (adding the United States government and its agencies to those by whom it may be assumed or guaranteed), or deposited as provided in section 5010; section 5010 is also amended to make deposits permissive rather than mandatory.

Section 5200 (Civil Code section 403c, subdivision 1, 1st paragraph) required the certificate of dissolution filed when a corporation has been wound up without court proceedings to state whether the known debts and liabilities of the corporation have been actually paid, or adequately provided for, or paid so far as its assets permit, or that there are no known debts and liabilities; section 5204 (Civil Codesection $403 \mathrm{c}$, subdivision 2 , 5th sentence of 1st paragraph) required the order of a court declaring a corporation dissolved to contain similar statements. Chapter 1231 adds to each section a provision that if there are known debts and liabilities for which adequate provision has been made, the certificate or order, as the case may be, shall state what provision has been made, setting forth the name and address of the corporation, person, or governmental agency that has assumed or guaranteed the payment, or the name and address of the depository with which deposit has been made, or such other information as may be necessary to enable the creditor to appear and claim payment. Since such certificates and orders are filed in the office of the Secretary of State and with the county clerk of the county in which the principal office of the corporation was located, inclusion of this information in the certificates and orders will enable a creditor to ascertain what provision has been made for the debt due him, and where to present 
his claim, without imposing any additional burden upon the dissolving corporation.

The Corporations Code as enacted ${ }^{11}$ is incomplete, since Title 2, Partnerships (to codify the Uinform Partnership Act, the Uniform Limited Partnership Act, and other code sections relating to partnerships), and Title 4, Securities (to codify the Corporate Securities Act, ${ }^{12}$ the "Bucket-Shop Law", ${ }^{13}$ the Security Owner's Protection Law, ${ }^{14}$ and the Retirement Systems Act) ${ }^{15}$ remain to be added to the code. The preparation of drafts of these titles is to be undertaken by the Code Commission in the immediate future, so that they may be presented to the legislature at its 1949 session. ${ }^{16}$

The General Corporation Law was also amended in 1947 by chapters $101^{17}$ and 794. ${ }^{18}$ Chapter 101 amends Corporations Code section 2218 to provide that where shares have been registered in the name of a nominee by a trust company acting as fiduciary, pursuant to section 105 of the Bank Act, such shares may be voted and all rights incidental thereto may be exercised by the nominee without proof of authority. Chapter 794 adds "any interested person" to those who may petition the superior court for determination of identity or appointment of directors or. trustees to wind up corporate affairs. ${ }^{10}$ It empowers the court to appoint one or more such directors or trustees, the number to be at the discretion of the court, regardless of the authorized number of directors or trustees, rather than only to replace those removed.

Chapter 850, adds Part 3.5, comprising section 10250, to Division 2, Nonprofit Corporations, of Title 1 of the Corporations Code. ${ }^{20}$ This section permits corporations sole and corporations for charitable or eleemosynary purposes (commonly known as "community chest organizations"), if so authorized by their articles of incorporation, to establish one or more common trust funds. Such a common trust fund

11 All of the Corporations Code bills prepared by the California Code Commission and enacted at the 1947 session of the legislature were introduced by Assemblymen $M$. Philip Davis, Marvin Sherwin, Ralph M. Brown, J. G. Crichton, and Donald L. Grunsky. 12 Cal. Stats. 1917, p. 673, Cax. GeN. Laws (Deering, 1944) ACT 3814.

13 Cal. Stats. 1923, p. 449, Cac. Gex. Laws (Deering, 1944) Act 972.

14 Cal. Stats. 1937, p. 2232, CaI. GeN. Laws (Deering, 1944) Act 3815.

15 Cal. Stats. 1945, p. 1996, CaL. Gen. Laws (Deering, supplement 1945) Act 5851.

${ }^{16}$ Copies, when available, may be obtained from Mr. Fred B. Wood, Secretary,

California Code Commission, 220 State Capitol, Sacramento, California.

1T The bill was introduced by Assemblyman Sherwin.

18 The bill was introduced by Assemblyman W. E. James.

18 CoRporations CODE $\$ 4804$.

20 The bill was introduced by Assemblyman Bernard R. Brady. 
is to be for the purpose of furnishing investments to any of the following:

(a) The corporation.

(b) Any church, parish, congregation, society, chapel, mission, religious, beneficial, or educational institution affiliated with it.

(c) Any organization, society or corporation holding funds or property for any organization mentioned in (a) or (b), or for the purpose of supporting a bishop, priest, religious pastor, or teacher, or any building used by or owned by any of the foregoing.

The new section authorizes these organizations to invest in shares or interests in such common trust funds any funds or property which they hold, unless the funds or property is held in a fiduciary capacity under an instrument prohibiting such an investment. The directors or trustees of a common trust fund are empowered to employ and fix the compensation of such officers and agents as they think best, including both appointment of a bank or trust company as custodian of the trust estate and employment of one or more investment advisers.

Subdivision (c) of section 10250 requires that the directors or trustees of such a common trust fund pay the net income of the trust in semiannual dividends to the holders of outstanding shares or beneficial certificates.

The creation, administration, and termination of such common trust funds, and participation in them are exempted from the Corporate Securities Act. ${ }^{21}$

Sections 2, 4, 5 and 16 of the Corporate Securities Act wereamended by chapters $198,130,1222$, and 129 , respectively, of the statutes of 1947.

The amendment to section 2 made by chapter 198 adds subsection 14 to subdivision (b); the new subsection exempts from the provisions of the Act any bona fide joint adventure interest, except when offered to the public. Chapter 198 also amends subsection 10 of the same subdivision to exempt guarantees of promissory notes, as well

21 For similar provisions concerning the establishment and administration of common trust funds by banks, trust companies, and other corporations qualified under the Bank Act to engage in the trust business in California see chapter 338 of the statutes of 1947. That chapter adds sections to the Bank Act, and a new article 6, relative to such common trust funds, to clapter 8 of the Personal Income Tax Law (Revenue and Taration Code, div. 2, part 10). The income of common trust funds so established and operated in accordance with the provisions of the Bank Act is exempted from taxation under the Personal Income Tax Law, and the funds themselves are exempted from taxation under the Corporation Income Tax Act and the Bank and Corporation Franchise Tax Act. 
as the notes themselves, when given or acquired in a bona fide way in the ordinary course of business, trade or commerce.

Chapter 130 amends section 4, relating to the power and duty of the commissioner of corporations to grant or refuse permits authorizing the issue and disposition of securities. These aunendments may well have resulted from the recent decision in Transportation Bldg. Co. v. Daugherty. ${ }^{22}$ Where the commissioner has heretofore been required to issue such a permit if he finds (among other things) that the proposed plan of business of the applicant is not unfair, or unjust, or inequitable, he is now required to issue the permit only where he finds both the proposed plan of business and the proposed issuance of securities fair, just and equitable. In the case of application for permit to issue securities in exchange for outstanding securities, claims or property interests, the commissioner is expressly authorized to refuse to issue a permit if in his opinion the plan is not fair, just, or equitable to all security holders affected.

The purposes for which the commissioner may impose conditions are broadened, so that he may now impose them as he deems necessary or advisable for the protection of the public and the purchasers of securities, rather than to insure the disposition of the proceeds of the securities in the manner and for the purposes provided in the permit. Waiver of assets and dividends by holders of promotional securities is enumerated among the conditions which may be so imposed.

A new paragraph has been added by chapter 1122 to section 5 of the Corporate Securities Act authorizing the commissioner of corporations, by rules and regulations adopted after reasonable notice and public hearing, to prescribe the rights, preferences, privileges, restrictions, and par value of securities proposed to be sold for the purpose of financing lawful racing enterprises; the par value so prescribed is not to exceed $\$ 1,000$ per share.

Any doubt which has existed as to the necessity of a permit for the sale of treasury shares is resolved by the amendment to section 16 made by chapter $129 . .^{23}$ As amended, section 16 now declares void every security of its own issue sold or issued by any company without permit, or, if authorized by the commissioner, in noncompliance with the provisions of the permit. ${ }^{24}$

22 (1946) 74 Cal. App. (2d) 604, 169 P. (2d) 470; see Note (1946) 34 CaLIF. L. REv. $741,745,749$.

23 The bill was introduced by Senator DeLap.

24 See Ballantine, The Curious Fiction of Treasury Shares (1946) 34 CArIr. L. REv. 536. 
* * * *

In the tax field, the 1947 legislation of widest application is chapter 780. It extends for one year (until January 1, 1949) the temporary reduction or "credit" in the bank and corporation franchise tax ${ }^{25}$ and in the corporation income $\operatorname{tax}^{26}$ originally made in 1943.27 These temporary reductions are continued also by chapter 1315 , which, in addition, specifies that the minimum franchise tax for nonexempt corporations shall be twenty-five dollars. Both chapter 780 and chapter 1315 eliminate the provision for transfer of a portion of the tax proceeds to the postwar employment reserve, and the regulations for the administration of that reserve. The reserve, however, continues in existence under chapter 572 of the statutes of 1943.

Under chapter 830 the date of dissolution of a corporation for franchise tax purposes is fixed as the date a copy of court decree, judgment or order, or certificate of winding up and dissolution is filed with the Secretary of State, and the date of withdrawal of a foreign corporation for such purposes is fixed as the date a copy of the withdrawal is filed with the Secretary of State. This chapter also authorizes the franchise tax commissioner to enter into a closing agreement concerning the franchise tax of any corporation, association, etc., which agreement becomes final upon approval by the State Board of Control. Chapter 831 gives the commissioner similar power in respect to the corporation income tax.

Extensive miscellaneous amendments to both the Bank and Corporation Franchise Tax Act and the Corporation Income Tax Act were made by chapter 1317 , approved July 10,1947, in effect immediately. The procedure for enforcing collection of the corporation income tax was modified by chapter 862 , and the procedure for collection of the franchise tax was modified similarly by chapter 1468 . An obsolete appropriation was deleted from the Corporation Income Tax Act by chapter 661 .

Codification of these tax acts in the Revenue and Taxation Code, originally contemplated for 1947, has been deferred until the 1949 session of the legislature, in order to allow more time for study and revision of the drafts prepared by the California Code Commission. ${ }^{28}$

25 Cal. Stats. 1943, p. 1579.

26 Ibid. p. 1580.

27 These 1943 reductions were continued by chapter 646 in 1945. Cal. Stats. 1945, p. 1290.

28 See note 16, supra. 